\title{
THE CHANGING ATTITUDES TO THE PHENOMENON OF DISABILITY IN RUSSIAN CULTURE AND PHILOSOPHICAL THOUGHT
}

\author{
G.I. Petrova, V.M. Smokotin, S.K. Gural \\ National Research Tomsk State University (Tomsk, Russian Federation) \\ E-mail: seminar2008@mail.ru
}

\begin{abstract}
The paper advances a thesis that the problem of disability is actively discussed at present not only in medicine, psychology and psychotherapy, but also in philosophy. This is explained by the anthropological turn that the contemporary philosophical thought is taking, and which makes it different from the classical period of development, when it displayed a purely rational and only logical interest in the essence of human being. The philosophical keenness on reason is now complemented with close attention to the problem of corporality, and, therefore, we may speak about including disability into the prerogative of the philosophical research.

Keywords: disability; illness; social well-being; the Other; cultural attitudes; philosophical anthropology.
\end{abstract}

\section{Introduction}

Disability, that is, "the otherness of individuation" presents itself as an extremely acute problem not only because nowadays it draws to itself the attention of politicians and social workers, but because it has found itself in the center of the contemporary philosophical and anthropological themes, which experience a post-metaphysical state and which include corporality as a legitimate research subject into the sphere of philosophical knowledge.

Since general philosophical principles are independent from political and ideological preferences and are based on metaphysics, they determine an essential vision of posing and solving any question. Certainly, national and historical specificity lays its sociocultural imprint on the philosophical vision of the problem of disability, but a philosophical invariant is retained in any mentality and any culture. The invariant community is based in this case on the philosophy of corporality, and understanding and practical solution of the question of disability are found depending on how the body has been viewed in the history of philosophy and on the attitude taken to it today. In this connection, it must be noted that an interest in disability problems was not characteristic for the classical period of the history of philosophy, as classical philosophy, starting from the times of antiquity, considered the body unworthy of being a subject of philosophy. Its subject was Logos-Reason. And, on the contrary, contemporary philosophy in its anthropological turn has seen 
the disabled person as a subject of its interest in the methodology of studying the world.

The aim of the paper is to provide a philosophical and anthropological substantiation of the attention to the problem of disability, which is displayed by public circles of various countries. More specifically, the paper aims to answer the question about the changes in contemporary philosophy that have contributed to medical sciences and social sciences (sociology, social psychology, politology, cultural studies etc.), taking up disability as a subject of their research.

\section{Subject and methods of research}

The subject of this paper's research is the disabled body in the notions of classical metaphysics (from Classical Antiquity to the $20^{\text {th }}$ century) and in contemporary post-metaphysical philosophical thought.

The research method is comparativism of philosophical and anthropological problems, comparing the attitude of philosophy to the research into the notion of the disabled body at different stages in the history of philosophy.

The authors' hypothesis is that a lack of attention to disability in the history of philosophy is explained by the primary classical philosophical intention to Reason. It is necessary to answer the question of how changes in the style of philosophical thinking manifest themselves in the character of scientific cognition of the world, influence the choice of the object of research in general and how, in particular, they have influenced the choice of such an object of research interest as the disabled person.

Classical philosophy, manifesting itself as gnoseology, was searching for ontological truth rationally purified from various sensual and corporeal features. The body in its states of health or illness perceives the world differently, and, therefore, it was considered that it could distort truth. As a consequence, it was proposed to ignore it in the process of cognition, which was regarded as a purely intellectual activity. Socrates' thesis, which has reached us due to Plato's dialogues, that "in death you are at home" speaks exactly about this necessity. As a philosophy of "pure reason" (Immanuel Kant), classical philosophy in its gnoseological part did not allow any corporeal strata.

It was only the $20^{\text {th }}$ century that provided the foundation for complementing the philosophy of consciousness with the philosophy of corporality, the latter bringing forth new research problems. The problem of the disabled body has found itself among the new philosophical problems: disability has entered philosophy as a legitimate object of research in its own right. Among the first who called attention to the "disabled body" was Michel Foucault [13]. Contemporary philosophers researching general problems of the philosophy of the body include Jean-Luc Nancy [4], Maurice Merleau-Ponty [5], Emmanuel Levinas [6], Valery A. Podoroga [7] and others. Some of the as- 
pects of this problem, e.g. gastronomy or gastronomic culture, have attracted research interest of J.-F. Revel [8], M.V. Dobrovolskaya [9], M.V. Kapkan [10], I.V. Sokhan [11] and others. A group of scholars researching the gender aspect of the problem of corporality includes T.A. Klimenkova [12], A. Rondarev [13], A. Nikonov [14], S. Firestone [15] and J. Kristeva [16]. Disability as the subject of research is presented in the works of Beate Fieseler [17], M.G. Muravyova [18], E. Iarskaya-Smirnova [19], P.V. Romanov [20] and Y.E. Barlova [21]. These authors draw attention to disability in the context of asocial problems (war, pauperism, poverty etc.) and raise the questions of charity. They are also concerned with social and medical questions of illness and social security.

It can be stated that despite the widespread understanding of the significance of the disability theme it has not been sufficiently investigated. Particularly, it may be said about Russia as a part of the world. Due to wellknown historical reasons, disability, even though it was within the research field of Russian academics, could not be accorded full and objective attention in concrete research work, since its findings could have led to undesirable results for the prestige of the country and its ruling circles (the magnitude of the problem, social insecurity, lack of attention to questions of psychological adaptation etc). However, recently disability has attracted to itself theoretical understanding, which is being embodied in concrete scientific and practical results.

\section{Obtained results}

\section{The problem of the body in classical philosophy}

The tradition of expultion of the body from philosophy came from Ancient Greece, and it was connected with the leading philosophical theme, Logos-Reason. Reason was directed towards the rational cognition of the world, which had not to be burdened with sensory strata, as the latter obscured the search for Truth. Truth was opening to Reason only from the depth of metaphysics. Reason, of course, could also cognize the body, but in rational cognition the body presented itself as a rational construction - its eidos. In the indicated ideal, the body in antique culture found its place either in the spheres of art - in the works of painters and sculptors, or sport - in gymnastic exercises, serving the training of youths for war, which in those times had to be waged almost continuously. The body was the body of Reason. Seen in such philosophical modus, the body had to be perfect, beautiful and strong, and it had to reject any non-similarity and otherness as compared with the body that had been created by the laws of Idea-Eidos. It could not be mutilated, deformed and horrible. The notion of corporal perfection, of the healthy body, of its formation and achieving complete mastery over it - 
was at the base of Greek medicine and medicalization of the entire Greek culture. But the healthy body interested medicine and philosophy, first of all, as the body for a healthy mind: "a healthy mind in a healthy body". This approach was used in the practices of the great physicians of antiquity Hipppocrates and Galen. Revulsion towards corporal weakness and an unhealthy body was intiated by the Platonian divarication of the world and the suggestion to connect truth, beauty and good only with the metaphysical, ideal world, as well as to reject all "the other", invalid, as repulsive, evil and untrue, to reject it as the low world of opinions, that is the world of nonknowledge. Weak, ailing and unhealthy "others" - invalids - did not enter the sphere judicious aristocratism. Thus, at the very start of its road, philosophy, having found Reason and emphasizing it, laid down the way of thinking, according to whose laws a culture was created that rejected corporeal problems.

The same principle of attitude to health with emphasis on the health and beauty not of the body but of the spirit was retained also in Middle Ages. The spirit (or mind) was in the center of anthropological, rational philosophical and religious investigations. "The Other" was associated with irrational and nonspiritual and, therefore, deficient. Thus, disability was considered as a deviation from Ratio, as a spiritual imperfection instilling fear and dread. "The Other" manifested itself as something ugly, monstrous and dreadful.

Thus, philosophy as the dominant of antiquity set an algorithm of a negative attitude to the problem of unhealthy and disabled body in culture.

\section{Posing the problem of the body in contemporary philosophy}

But the $20^{\text {th }}$ century placed philosophy before comprehending the new anthropological situation when the notion of the human being reduced to a classical transcendental subject lost its power, and humans found themselves not only in the sphere of the ideal - conscience and spirit, but gave to their material and corporal existence its due. The body and corporality acquired legitimation in the area of philosophical reasoning not on the conditions of a deviation from the ideal of a perfect body (which generated contempt as the subject of the doxa), but as an anthropological problem within the competence of philosophy. The $20^{\text {th }}$ century proved to be the start of a new thought about the body.

Changes in the philosophical thinking of the $20^{\text {th }}$ century were connected with deconstructive processes in philosophy: the philosophical reason acquired the quality of tolerance - of the tolerant attitude towards "the Other". There arose the problem not only of the mind, but of the body. The body presented itself as one of the vital and central problems addressed by philosophy. It was at that time that the task of its substantiation, realization and the development of a theoretical concept was set [22]. 
Thus, contemporary philosophy includes the body into its range of research problems. Humans are spiritual and corporeal beings. And if classical philosophy engaged in theoretical reflection of homo sapiens, homo faber etc., contemporary philosophy, inheriting this base, creates on it a living human presence, Dasein (see Heidegger, [23]).

This seemingly apparent theoretical proposition entered philosophy in the $20^{\text {th }}$ century, and made scholars rethink its metaphysical orientation in emphasizing the ontological range of problems. New research directions in philosophy provided a stimulus for a new attitude to the problem of corporality due to the same new perspective on reason. First of all, a legitimation of the sensory stage of thinking took place, which led to the understanding of the unity of corporeal and sensory aspects. The intellect presented itself in an emotional way. "The emotional intellect" asserted the impossibility of the "pure reason", on the one hand, and - of the "pure contemplation", on the other hand. New philosophical directions emerged, which, in their turn, stimulated a new attitude to the given problem. Nowadays, the view of reason is reconsidered when a necessity is obviated for its "hermeneutic inoculation" [24] and the non-identity of the notions of conscience and spirit is revealed. It is affirmed that human beings are coming out into the world, get in contact with it and find themselves in accord with it by means of sensory perception [5]. The body with which a person gets in contact with the Other [Ibid.] and with which it "thinks" [25] creates a need for seeing the world as not only born from transcendental height by a regulative reason but for feeling it corporeally. An individual gets in contact with being in a sensorial way, experiences pleasure, joy and happiness. Or on the contrary, he or she experiences pain, suffering or grief. It is here - in the existentials of the internal world of the individual - that philosophy has found the beginnings of human life.

Attention to the body on the side of contemporary philosophy and philosophical anthropology has initiated addressing the problem of disability, which is subjected to reflection and which problematizes the classical idea of human beings only in their rational, reasonable essence.

Disability is a corporeal experience of individuals, who are aware of existing on the border between being and non-being. The borderline is experienced by means of a dramatic fullness of a person's existentional world. A disabled individual is aware of his or her otherness. His or her life's drama is in that he or she is different and that what he or she feels is unaccessable to others and, therefore, a disabled individual must look for a life support only in himself or herself.

Thus, disability is one of the vital problems of philosophical anthropology, and disability research differs from classical anthropological perspective, which displayed only rational and purely logical interest in the essence of a human being. At present, we may speak about including disability 
as a problem of corporality in philosophy, which has never shown any interest in disability in the past and has not paid it much attention.

It must be noted, however, that having come in the limelight, disability as a problem of corporality has not yet become a dominant theme among those that have come into philosophy, having broken its primary emphasis on reason. Much greater attention in philosophical and culturological range of problems is paid to the sphere of corporeal practices and techniques. An active propaganda of the healthy way of life, of the beautiful body, bodybuilding and body art, as well as the importunity of recipes for slimming and attention to dancing culture etc. - all these are manifestations of contemporary interest in the problem of corporality. In the same perspective, we should view the processes and procedures biologizing the anthropological range of problems which are actively discussed in media and social networks: change of sex, plastic operations, creonics, transhumanism, surrogate motherhood etc.

Having emerged as a problem of corporal pathology, disability has not received the positive connotation that has become characteristic of the problem of corporality on the whole. And the disabled body is still considered from a negative perspective, or social attention is drawn to it with a certain shade of pity and secondariness. Even today solving this problem is encumbered with a historical burden of defining disability as some form of otherness in relation to reasonableness. Philosophy, as a cultural dominant of antiquity, having set an algorithm of attitude to the problem of disability in culture, does not give it up.

However, interest in defining the notion of "a disabled person" is displayed nowadays, apart from philosophy, by other spheres of cultural life. Therefore, defining this notion depends not only on the state of philosophy and the solving abilities of its style of thinking, which is setting concrete borders to reflecting on some problems, including this one. Understanding disability depends to a large degree on the character of the political regime, the economic state of society, national mentality and cultural traditions, which have been formed in the course of history. Disability is an interdisciplinary problem. In Russia, it arises not only as a medical problem but, first of all, as a problem of social life.

Thus, it was not only a philosophical negation of the body that lay at the basis of the notion of "a disabled person" in Russia in the period of Stalin's authoritarian rule, when the anthropological problem was reduced in its content to understanding a human being purely as a "productive unit". Moreover, the regime's ideological orientation, which strove to conceal its negative aspects, consciously refused to regard the problem of disability as demanding solution. Disability ceased to be considered or was ignored from the perspective of human health, and acquired exclusively a meaning associated with industrial production. For this reason, for example, in the Soviet 
manual about labor placement of invalids [26], groups of disability were set and criteria indicated for referring a disabled person to one of them. The criteria were based not on individuals' state of health, but on the degree of their ability to carry out production activities (Fieseler, [17]. As for the Letter of Instruction about the Work of the Medical Labor Commission of Experts in Wartime [27], disability as a corporeal problem is not mentioned at all, but the document speaks about the social problem of ability to work. Such substitution has been finding its cynical justification in the suggestion to understand labor as a health-building procedure [28: 611].

When speaking about the contemporary state of the research into the problem of disability in Russia, it can be stated that in 1990s the question of disabled person's identity was brought up as a matter of urgency. The task was in identifying disability as a philosophical and an anthropological problem. Philosophy demonstrated its interest in a disabled person, first of all, as in a human being who in case of illness stays as such. The illness of the disabled persons certainly influences their identities. But an influence, whether social or physiological (e.g., on the basis of gender, social inequality, age) is experienced by other groups of people, and a disabled person must not differ from others in this respect. He or she is as much the "Other", as every individual is the "Other". A philosophical and anthropological approach to the problem of disability has stimulated other spheres of knowledge to look not only for the medical aspect of its solution, but to treat disabled persons from the point of view of including them into an active social life. A disabled person's adaptation is understood as feasible for realization if it is taking place in a situation of refusal from considering disability as a medical diagnosis and an illness, and, on the contrary on the basis of accepting disabled persons as equal to other groups of people and including them in an active social life. Such is the leitmotif of contemporary research in this problem's field.

\section{Conclusion}

There are two channels in every mentality through which politics, social relations and power can use the problem of corporality in their concrete interests: pain and pleasure. Using these levers, the state, society and separate social groups can manipulate individuals. The disabled person perceives society through such kind of sensorial feelings - through pain. The humanism of philosophical knowledge has revealed itself in its initiative attention to the problem of disability. It is the character and direction of philosophical and anthropological knowledge that determine to a great extent the practical solution of providing disabled persons with such living conditions in which they would not feel their social otherness. 
An analysis carried out from the positions of philosophical anthropology brings us to the conclusion that the researchers in the fields of social and behavioral sciences should render more active their research on the theme of disability. Joint and interdisciplinary research will allow scientists to work out theoretically characteristics of disability, which, in its turn, can contribute to the relevant answers to the questions: "What is a human being?", "What is a specific nature of human existence?" and "What does it mean to be human?"

\section{Acknowledgements}

The paper's authors express their gratitude to those authors who have taken up the theme of disability earlier and continue to do their research in this field at present and who have helped us in writing this paper on the urgent problem of disability in Russia.

\section{References}

1. Foucault, M. (2006). History of Madness. (Trans. by J. Murphy and J. Khalfa). London: Routledge.

2. Foucault, M. (1995). Discipline and Punish: the Birth of the Prison. (Trans. by Alan Sheridan). New York: Random House.

3. Foucault, M. (2003). The Birth of the Clinic: An Archaeology of Medical Perception Hove, East Sussex, UK: Psychology Press.

4. Nancy, J.-L. (1992). Corpus. Paris: Métailie.

5. Merleau-Ponty, M. (2012). Phenomenology of Perception. (Trans. by D.A. Landes). New York: Routledge.

6. Levinas, E. (1991). Totality and Infinity. Dordrecht, the Netherlands: Kluwer Academic Publishers.

7. Podoroga, V.A. (1995). Phenomenology of the body. Moscow: Ad Marginem.

8. Revel, J.-F. (2007). Un Festin en parole: histoire littéraire de la sensibilité gastronomique de l'Antiquité à nos jours. Paris: Tallandier.

9. Dobrovolskaya, M.V. (2005). Humans and their Food. Food Specializations and Problems of Anthropogenesis. Moscow: Nauchnyi Mir.

10. Kapkan, M.V. (2010). The Phenomenon of Gastronomic Culture: Specifics of Representation Forms. Abstract of the thesis in cultural studies. Yekaterinburg: Urals State University. URL: http://elar.urfu.ru/bitstream/10995/2671/1/urgu0766s.pdf

11. Sokhan, I.V. (2011). Fast food as a vital gastronomic consumption practice. The Journal of Sociology and Social Anthropology. 5 (58). pp. 251-269.

12. Klimenkova, T. (1996). Woman as a Phenomenon of Culture. A view from Russia. Moscow: Preobrazhenie.

13. Rondarev, A. On the Predestination of Woman. URL: http://news.rambler.ru/28875887/

14. Nikonov, A. (2005). The End of Feminism. In what woman differs from man. Moscow: ENAS.

15. Firestone, Sh. (2003). The Dialectic of Sex: the Case for Feminist Revolution. New York: Farrar Straus Giroux. 
16. Kristeva, J. (1987). In the Beginning was Love: Psychoanalysis and Faith. New York: Columbia University Press.

17. Fieseler, B. (2015). Arme Sieger. Die Invaliden des "Grossen Vaterländischen Krieges" der Sowietunion 1941-1945. Vienna: Böhlau Verlag.

18. Muravyova, M.G. (2013). Cripples, Invalids or Special Needs Persons? A Review of the History of Disability (in Russian). The Journal of Social Policy Studies. 10 (2). pp. 151156.

19. Iarskaya-Smirnova, E. (2002). The Bravery of Disability. Moscow: NLO.

20. Romanov, P.V., Iarskaya-Smirnova, E. (2011). Body and Discrimination: Disability, Gender and Citizenship in Post-Soviet Cinematography (in Russian). Neprikosnovennyi Zapas. 2. pp. 76.

21. Barlova, Yu.E. (2010). Pauperism, beggary and social care in social and political thought of the $18^{\text {th }}-19^{\text {th }}$ centuries. Nauka i Shkola. 2. pp. 118-121.

22. Rozin, V.M. Body and Corporality as Anthropological Construction. URL: $\mathrm{http} / /$ bookucheba.com/sotsialnaya-filosofiya-knigi/telo-telesnost-kak-antropologicheskaya-28159.html

23. Heidegger, M. (2010). Being and Time, trans. by Joan Stambaugh. Albany, NY: State University of New York Press.

24. Ricoeur, P. (1974). The Conflict of Interpretations: Essays in Hermeneutics, transl. by Willis Domingo et al. Evanston: Northwestern University Press.

25. Schusterman, R. (2006). Thinking by the Body. Voprosy Filosofii. 6. pp. 52-67.

26. (1952). Labor Placement of Invalids. Manual for Social Security Inspectors. Moscow.

27. Letter of Instruction on the work of the Medical Labor Commission of Experts in Wartime (1941, August 9). The State Archive of the Russian Federation. F. A-413. In. 1. C. 234. Sh. 182-183.

28. (1952). Disability. The Great Soviet Encyclopedia. 17. pp. 611.

Resived 02.05.2017

Information about the authors:

Petrova Galina - D.Sc. (Philosophy), Professor, Faculty of Philosophy, National Research Tomsk State University (Tomsk, Russian Federation). E-mail: seminar2008@mail.ru

Smokotin Vladimir - D.Sc. (Philosophy and Culture), Professor, Faculty of Foreign Languages, National Research Tomsk State University (Tomsk, Russian Federation). E-mail: vladimirsmokotin@yandex.ru

Gural Svetlana - Ds.Sc. (Education), Professor, Faculty of Foreign Languages, National Research Tomsk State University (Tomsk, Russian Federation). E-mail: gural.svetlana@mail.ru 